\title{
Analysis of Vegetation Lichens of Corticolous on the Styrax Sp. in Aek Nauli Forest Simalungun and Tahura, Karo North Sumatera, Indonesia
}

\author{
Ashar Hasairin $^{1}$, Tri Harsono ${ }^{2}$, Rosliana Siregar ${ }^{3}$ \\ \{nst.ashar@yahoo.com $\}$ \\ Biology FMIPA State University of Medan ${ }^{1,2}$, FKIP University Moslem of North Sumatera ${ }^{3}$
}

\begin{abstract}
Other research aims to obtain data on vegetation analysis of species lichens in Aek Nauli-Forest and TAHURA, Karo North Sumatera. This study transect method, determination of tree stands in purpossive sampling with exploratory surveys and inventories, is descriptive. The results showed a high diversity and obtained 22 species of lichens, the 19 species in Aek Nauli and 14 species in TAHURA. Thallus lichens forms encountered on two locations: crustose, foliose and fruticose. Data analysis Relative Density (RD) of Vegetation Relative Frequency (FR) Relative Dominance (RDm) and Importance Value (IV), the highest for Aek Nauli consecutive Pyrhospora quernea the type $(25.56 \%, 15.52 \% ; 25,56 \%$ and $68.63 \%$ ). Data analysis of RD; FR; RDm and IV for the highest consecutive Tahura the type of Pertusaria amara $(24.80 \%, 21.05 \%, 24.80 \%$ and $70.64 \%)$. Almost all types of lichens both locations showed clumped distribution pattern and one type which shows a random distribution pattern. Through measurements of physico-chemical factors on the standing tree Styrax sp. Aek Nauli obtained in air temperature, air humidity and light intensity on average $(22.90 \mathrm{C}, 60 \% ; 827.1$ Joules). While in the TAHURA, has a temperature, humidity and light intensity on average (21.20C; $77.9 \%, 894.4$ Joules).
\end{abstract}

Keywords: Vegetation, Lichens, Corticolous, Styrax

\section{Introduction}

Lichens can grow in almost all places such as on rocks, soil and tree stands, one of which is in the stands of incense trees. The incense tree has an upright/straight stem with little branching. The bark is grooved until it cracks in a vertical direction or is smooth notched, grape red skin. The inner skin is soft, brown to red, pink or purplish red. The shape of the thallus lichens found in the frankincense tree stands usually in the form of crustose, foliose, fruticose, and squamulose (Hasairin, et al. 2014).

Based on data from Bogor Herbarium Bogoriensis, lichens in Indonesia number 40,000 species, but not many researchers in Indonesia have pursued this research, so the opportunity to research lichens in Indonesia is still wide open and potentially (Pratiwi, 2006). The fact that is known and displayed in biology books shows that only a few species are known, even though the number reaches 40,000 species. In addition to the types, the benefits of Lichens have also not been widely reviewed (Pratiwi, 2006). Furthermore Darma et al. (1998) found several types of lichens, in pine stands, among others: Parmelia reticulata, Crusta sp. and Staurothele sp., whereas in rubber stands found Parmelia sp., Parmelia reticulata, Verrucaria sp. and one species belonging to Lichens imperfecti. Thallus Parmelia reticulata is found to develop in pine and rubber trees.

Forest area is very potential for habitat growth of the lichens. One of them is the Aek Nauli-Parapat Protection Forest and the Bukit Barisan Grand Forest Park (TAHURA), Tongkoh. This forest is located in North Sumatra which is a tropical rain forest ecosystem which is the habitat of living things. These forests have not been much researched on flora and fauna, although there are only a few protected forests and nature reserves that specifically examine flora and fauna, but research on the diversity and distribution of lichens is still rare, such as in the Aek Nauli forest area, Parapat, Simalungun Regency and Forest Park (TAHURA) Bukit Barisan, Karo District. Both of these forest areas can be used as research locations. The vegetation type can be divided into three, namely shrub vegetation type, secondary forest and primary forest from lowland to highland reaching a height of $\pm 2000 \mathrm{~m}$ altitude above sea level. The topography is flat to hilly with the slope of clay and 
sandy land. This forest area has a wet month (rainfall of $7200 \mathrm{~mm} /$ month) for nine consecutive months, a temperature range between $16.8^{\circ} \mathrm{C}-23^{\circ} \mathrm{C}$, and high humidity $\pm 80 \%$ (Tjitrosoepomo, 1989); (Sipman, 2003).

Based on the description above, it is necessary to conduct research on "Analysis of Lichens Vegetation in Frankincense Tree Stands (Styrax sp.) In the Aek Nauli Forest Area - Parapat in Simalungun District and TAHURA Forest Park Bukit Barisan, Karo District, Nort Sumatera".

\section{Materials and methods}

Research done in the area of Aek Nauli-Forest and TAHURA Karo, Sumatera Utara. Sample is the types of lichens that grow on the bark (corticolous) of the Kemenyan (Styrax sp.) tree. Tool used for collections; tool measuring habitat and physical properties of the media grows; microscopic observations tool. Ingredients aquades, alcohol $70 \%$, laktofenol-analin blue, tissue preparations making. The study was descriptive by the exploratory survey and inventory. Types of tree stands are researched is Kemenyan (Styrax sp.) with 10 trees each location. Determination of tree stands with "Purpossive sampling". The technique of sampling method "Vertical Transek" upward as high as 4 meters (Hasairin, et al, 2014). For the first two meters created as plots one and two metres to- 2 as the two plots. The number of plots of trees stands by as much as $15 \times 2=30$ plots. Any species of lichens collected for purposes of identification and documentation. For identification using the reference "Key to the lichens genera identification using the reference "Key to the lichens genera book "Grasses, Ferns, Mosses \& Lichens" (Sipman, 2003). Data analysis calculates the number of thallus, the percentage of attendance, the vegetation, the index of diversity using the formula Shannon-Wiener. The distribution pattern.

\section{Results and discussion}

\subsection{Deskription of the research location}

Aek Nauli has a protected forest area of tropical forest with an area of approximately 2,500 $\mathrm{Ha}$, located in North Sumatra Province, Simalungun Regency, Girsang Sipangan Bolon District, at $20^{\circ} 41^{\prime}$ to $20^{\circ} 44^{\prime} \mathrm{LU}$ and $98^{\circ} 57^{\prime}$ to $98^{\circ} 58^{\prime} \mathrm{BT}$ with a height of approximately $1,200-1,400 \mathrm{~m}$ altitude is above sea level. Tofography is flat, bumpy and hilly and has a complete spread of forest vegetation. The total area is $\pm 2,500 \mathrm{Ha}$ and the research forest is around $300 \mathrm{Ha}$ while the rest is asylum forest.

Tahura Bukit Barisan is the third Tahura in Indonesia determined by the President with a Presidential Decree R.I. No. 48 of 1988 on November 19, 1988. Tahura Bukit Barisan is a management unit that has core areas of protected forests and conservation areas with a total area of 51,600 Hektar. Place height $\pm 1400-2000$ meter altitute above sea level.

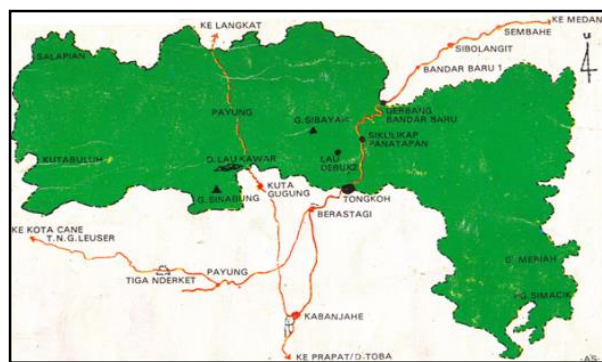

(a)

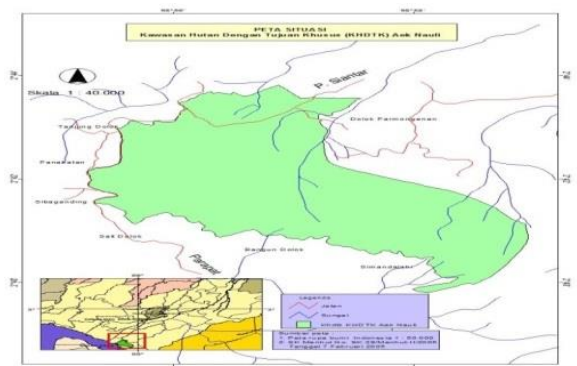

(b)

Fig. 1. Location Research a) TAHURA Bukit Barisan; b) Aek Nauli Forest Area 


\subsection{Lichens found in both study location}

Based on the results of the research conducted at the two study sites there were 22 species from 11 genera. For the Aek Nauli forest area as many as 19 species and in the TAHURA region as many as 14 species. Lichens identified according to Misra and Agrawal refer to "Key to the lichens genera of Bogor, Cibodas and Singapore" (Sipman, 2003), "Key to the Lichen Genera of the Pacific Northwest (McCune, 2010)" and with reference ooks "Grasses, Ferns, Mosses \& Lichens" (Phillips, 1990). The genus is divided into genus Cladonia, Graphis, Lecanora, Lepraria, Parmelia, Peltigere, Pertusaria, Pyrenula, Rimelia, Usnea and Verrucaria. Of the 22 species of lichens found in the two study locations in the frankincense tree stand, there was a diversity that was so varied from one another. Comparison types of lichens, number of colonies and diversity index are shown in Table 1.

Table 1. Comparison and lichens diversity index in research sites

\begin{tabular}{|c|c|c|c|c|c|c|c|c|c|c|c|}
\hline \multirow{2}{*}{ No. } & \multirow{2}{*}{ Species } & \multicolumn{5}{|c|}{ Aek Nauli (Parapat) } & \multicolumn{5}{|c|}{ Tahura (Karo) } \\
\hline & & $\Sigma$ & $(\%)$ & $\mathbf{P i}$ & ln pi & $\mathbf{H}^{\prime}$ & $\sum$ & $(\%)$ & $\mathbf{P i}$ & $\ln \mathbf{p i}$ & $\mathbf{H}^{\prime}$ \\
\hline 1 & $\begin{array}{l}\text { Cladonia } \\
\text { coniocrae } \\
a\end{array}$ & - & - & - & - & - & 8 & 0.82 & 0.008 & -4.80 & 0.04 \\
\hline 2 & $\begin{array}{l}\text { Graphis } \\
\text { scripta }\end{array}$ & 2 & 0.11 & 0.001 & $\begin{array}{l}- \\
6.78\end{array}$ & 0.01 & 4 & 0.41 & 0.004 & -5.50 & 0.02 \\
\hline 3 & $\begin{array}{l}\text { Graphis } \\
\text { elegans }\end{array}$ & - & - & - & - & - & 6 & 0.61 & 0.006 & -5.09 & 0.03 \\
\hline 4 & $\begin{array}{l}\text { Lecanora } \\
\text { conizoides }\end{array}$ & 80 & 4.53 & 0.045 & $\begin{array}{l}- \\
3.09\end{array}$ & 0.14 & $\begin{array}{l}12 \\
5\end{array}$ & $\begin{array}{l}12.8 \\
1\end{array}$ & 0.128 & -2.06 & 0.26 \\
\hline 5 & $\begin{array}{l}\text { Lecanora } \\
\text { thysanoph } \\
\text { ora }\end{array}$ & 78 & 4.42 & 0.044 & $-\overline{3.12}$ & 0.14 & 20 & 2.05 & 0.020 & -3.89 & 0.08 \\
\hline 6 & $\begin{array}{l}\text { Lepraria } \\
\text { incana }\end{array}$ & $\begin{array}{l}14 \\
4\end{array}$ & 8.15 & 0.053 & $-\overline{2.93}$ & 0.16 & $\begin{array}{l}17 \\
2\end{array}$ & $\begin{array}{l}17.6 \\
3\end{array}$ & 0.173 & -1.75 & 0.30 \\
\hline 7 & $\begin{array}{l}\text { Lepraria } \\
\text { vouauxii }\end{array}$ & 9 & 0.51 & 0.005 & $-\overline{5.28}$ & 0.03 & - & - & - & - & - \\
\hline 8 & $\begin{array}{l}\text { Lepraria } \\
\text { sp. }\end{array}$ & - & - & - & - & - & 23 & 2.36 & 0.024 & -3.75 & 0.09 \\
\hline 9 & $\begin{array}{l}\text { Lepraria } \\
\text { umbricola }\end{array}$ & 78 & 4.42 & 0.044 & $\begin{array}{l}- \\
3.12\end{array}$ & 0.14 & - & - & - & - & - \\
\hline 10 & $\begin{array}{l}\text { Parmelia } \\
\text { saxatilis }\end{array}$ & 46 & 2.60 & 0.026 & - & 0.10 & - & - & - & - & - \\
\hline 11 & $\begin{array}{l}\text { Parmelia } \\
\text { plumbea }\end{array}$ & 59 & 3.34 & 0.033 & - & 0.11 & 4 & 0.41 & 0.004 & -5.50 & 0.02 \\
\hline 12 & $\begin{array}{l}\text { Parmelia } \\
\text { caperata }\end{array}$ & 42 & 2.38 & 0.024 & - & 0.09 & 6 & 0.61 & 0.006 & -5.09 & 0.03 \\
\hline 13 & $\begin{array}{l}\text { Peltigere } \\
\text { sp. }\end{array}$ & 36 & 2.04 & 0.020 & - & 0.08 & 9 & 0.92 & 0.009 & -4.69 & 0.04 \\
\hline 14 & $\begin{array}{l}\text { Pertusaria } \\
\text { amara }\end{array}$ & $\begin{array}{l}23 \\
1\end{array}$ & $\begin{array}{l}13.0 \\
8\end{array}$ & 0.131 & - & 0.27 & $\begin{array}{l}24 \\
2\end{array}$ & $\begin{array}{l}24.8 \\
0\end{array}$ & 0.248 & -1.39 & 0.35 \\
\hline 15 & $\begin{array}{l}\text { Pyrenula } \\
\text { nitida }\end{array}$ & 21 & 1.19 & 0.012 & - & 0.05 & 32 & 3.28 & 0.033 & -3.42 & 0.11 \\
\hline 16 & $\begin{array}{l}\text { Pyrenula } \\
\text { sp. }\end{array}$ & 84 & 4.76 & 0.048 & $\begin{array}{l}- \\
3.05\end{array}$ & 0.14 & - & - & - & - & - \\
\hline
\end{tabular}




\begin{tabular}{|c|c|c|c|c|c|c|c|c|c|c|c|}
\hline 17 & $\begin{array}{l}\text { Pyrhospor } \\
\text { a quernea }\end{array}$ & $\begin{array}{l}46 \\
9\end{array}$ & $\begin{array}{l}26.5 \\
6\end{array}$ & 0.266 & $-\overline{1.33}$ & 0.35 & $\begin{array}{l}22 \\
0\end{array}$ & $\begin{array}{l}22.5 \\
4\end{array}$ & 0.225 & -1.49 & 0.34 \\
\hline 18 & $\begin{array}{l}\text { Rimelia } \\
\text { reticulate }\end{array}$ & 90 & 5.10 & 0.051 & - & 0.15 & - & - & - & - & - \\
\hline 19 & $\begin{array}{l}\text { Usnea } \\
\text { dasypoga } \\
\text { Usnea }\end{array}$ & 96 & 5.44 & 0.054 & 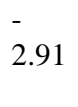 & 0.16 & - & - & - & - & - \\
\hline 20 & $\begin{array}{l}\text { fillipendul } \\
a\end{array}$ & 12 & 0.68 & 0.007 & $\overline{4} .99$ & 0.03 & - & - & - & - & - \\
\hline 21 & $\begin{array}{l}\text { Verrucari } \\
\text { a Maura }\end{array}$ & $\begin{array}{l}18 \\
4\end{array}$ & $\begin{array}{l}10.4 \\
3\end{array}$ & 0.101 & - & 0.23 & $\begin{array}{l}10 \\
5\end{array}$ & $\begin{array}{l}10.7 \\
6\end{array}$ & 0.042 & -3.17 & 0.13 \\
\hline 22 & $\begin{array}{l}\text { Verrucari } \\
a \mathrm{sp.}\end{array}$ & 5 & 0.28 & 0.003 & $\begin{array}{l}- \\
5.87\end{array}$ & 0.02 & - & - & - & - & - \\
\hline Total & & $\begin{array}{l}17 \\
66\end{array}$ & 100 & - & 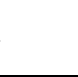 & 2.52 & $\begin{array}{l}97 \\
6\end{array}$ & 100 & - & - & 2.05 \\
\hline
\end{tabular}

Based on Table 1 the highest percentage of lichens found in Aek Nauli, Parapat, Simalungun Regency is a Pyrernospora quernea with a value of $26.56 \%$. The highest percentage of lichens in TAHURA Bukit Barisan Karo Regency is Pertussaria amara with a value of $24.80 \%$. While the lowest percentage of lichens found in Aek Nauli forest is a Graphis scripta with a value of $0.11 \%$. The lowest percentage of lichens in TAHURA Karo Regency is a Graphis scripta with a value of $0.41 \%$.

By looking at the highest percentage of lichens in the two study locations there were differences in species. This is most likely influenced by the ecological conditions of the environment where the lichens grow. According to Pratiwi (2006) the growth of lichens is influenced by several environmental factors including air temperature, air humidity, and air quality (Pratiwi, 2006).

The diversity value in Aek Nauli - Parapat, Simalungun Regency is $H{ }^{\prime}=2.52$, while in TAHURA Bukit Barisan Tongkoh - Karo Regency is $\mathrm{H}^{\prime}=2.05$ which according to Odum (1993) is in good condition (high) because of the value $\mathrm{H}^{\prime}>2$ (Odum, 1993). This situation is acceptable given the location of the study is relatively fertile and has physical chemical factors that are very supportive for the growth and development of lichens. Species diversity is influenced by the distribution of individuals in each type, because a community even though there are many species, but if the distribution of individuals is not evenly distributed, species diversity is low.

The high diversity seen shows the stability of the community in it. This is because the two research locations are classified as primary forests with relatively high heterogeneity. Barbour said that a community is said to have high species diversity if the community is composed by many species with an abundance of the same or almost the same species (Barbour, et al. 1987). Next (Odum, 1993) states that the more the number of species, the more diversity. In this study, diversity ( $\left.\mathrm{H}^{\prime}\right)$ is higher in the location of the Aek Nauli forest area - Parapat compared to TAHURA, Tongkoh - Karo Regency.

Lichens in the frankincense tree stands generally have different characteristics in terms of shape, color and also their lushness. The shape of the thallus lichens found in both locations varies, consisting of elongated, rounded and irregular shapes. The shape of the lichens in the incense stand for the crustose type lichens tends to be elongated and irregular. This situation can be found in the genus Phyrospora and Pertussaria. According Pratiwi states the shape of the thallus, especially for the crustose type, will be found dam forms that are not fixed and 
some types of lichens have a thallus shape which tends to resemble a circle but can also be found in irregular conditions (Pratiwi, 2006); (Hasairin, et al. 2014).

\subsection{Analysis of the vegetation lichens risearch location}

The vegetation in the forest area of the lichens Aek Nauli - Parapat and TAHURA, Bukit Barisan, Kabupaten Karo very in detail are presented in Table 2.

In Table 2 the highest vegetation analysis data is in the form of Relative Density (KR); Relative Frequency (FR); Relative Dominance (DR) and Important Value (NP); the highest was for Aek Nauli, respectively, namely Pyrhospora quernea $(25.56 \% ; 15.52 \% ; 25.56 \%$ and $68.63 \%$ ) and the lowest in Graphis scripta. While KR analysis data; FR; The highest DR and NP for Tahura were Pertusaria amara $(24.80 \% ; 21.05 \% ; 24.80 \%$ and $70.64 \%)$ respectively.

The highest Important Value Index (INP) found in the Aek Nauli forest - Parapat Simalungun Regency is Pyrhospora quernea with a value of $68.63 \%$. The highest important value found in TAHURA - Karo District is Pertusaria amara with a value of $70.64 \%$. This means that Pyrhospora quernea and Pertusaria amara species are the most dominant types of lichens along the study area, can be seen in the sampling table of lichens in both study locations

Table 2: Vegetation lichenes in two research location

\begin{tabular}{|c|c|c|c|c|c|c|c|c|c|}
\hline \multirow[b]{2}{*}{ No } & \multirow[b]{2}{*}{ Species } & \multicolumn{3}{|c|}{ AEK NAULI } & \multicolumn{3}{|c|}{ TAHURA } & \multicolumn{2}{|l|}{ IVI } \\
\hline & & RD & $\mathbf{R F}$ & $\begin{array}{l}\mathbf{R D} \\
\mathbf{m}\end{array}$ & RD & $\mathbf{R F}$ & DRm & $\begin{array}{l}\text { Aek } \\
\text { Nauli }\end{array}$ & $\begin{array}{l}\text { Tahu } \\
\text { ra }\end{array}$ \\
\hline 1 & $\begin{array}{l}\text { Cladonia } \\
\text { coniocraea }\end{array}$ & - & - & - & 0.82 & 1.05 & 0.820 & - & 2.69 \\
\hline 2 & Graphis scripta & 0.11 & 0.86 & 0.11 & 0.41 & 2.11 & 0.410 & 1.09 & 2.92 \\
\hline 3 & Graphis elegans & - & - & - & 0.61 & 2.11 & 0.615 & - & 3.33 \\
\hline 4 & $\begin{array}{l}\text { Lecanora } \\
\text { conizoides }\end{array}$ & 4.53 & 1.72 & 4.53 & 12.81 & 9.47 & $\begin{array}{l}12.80 \\
7\end{array}$ & 10.78 & 35.09 \\
\hline 5 & $\begin{array}{l}\text { Lecanora } \\
\text { thysanophora }\end{array}$ & 4.42 & 2.59 & 4.42 & 2.05 & 2.11 & 2.049 & 11.42 & 6.20 \\
\hline 6 & Lepraria incana & 5.32 & 8.62 & 5.32 & 17.32 & $\begin{array}{l}15.7 \\
9\end{array}$ & $\begin{array}{l}17.31 \\
6\end{array}$ & 19.27 & 50.42 \\
\hline 7 & $\begin{array}{l}\text { Lepraria } \\
\text { umbricola }\end{array}$ & 0.11 & 0.86 & 0.11 & - & - & - & 1.09 & - \\
\hline 8 & $\begin{array}{l}\text { Lepraria } \\
\text { vouauxii }\end{array}$ & - & - & - & 2.36 & 3.16 & 2.357 & - & 7.87 \\
\hline 9 & Lepraria sp. & 4.42 & 3.45 & 4.42 & - & - & - & 12.28 & - \\
\hline 10 & $\begin{array}{l}\text { Parmelia } \\
\text { saxatilis }\end{array}$ & 2.60 & 4.31 & 2.60 & - & - & - & 9.52 & - \\
\hline 11 & $\begin{array}{l}\text { Parmelia } \\
\text { plumbea }\end{array}$ & 3.34 & 6.90 & 3.34 & 0.41 & 1.05 & 0.410 & 13.58 & 1.87 \\
\hline 12 & $\begin{array}{l}\text { Parmelia } \\
\text { caperata }\end{array}$ & 2.38 & 3.45 & 2.38 & 0.61 & 1.05 & 0.615 & 8.2 & 2.28 \\
\hline 13 & Peltigere sp. & 2.04 & 3.45 & 2.04 & 0.92 & 6.32 & 0.922 & 7.53 & 8.16 \\
\hline 14 & Pertusaria amara & 13.08 & 9.48 & $\begin{array}{l}13.0 \\
8\end{array}$ & 24.80 & $\begin{array}{l}21.0 \\
5\end{array}$ & $\begin{array}{l}24.79 \\
5\end{array}$ & 35.64 & 70.64 \\
\hline
\end{tabular}




\begin{tabular}{|c|c|c|c|c|c|c|c|c|c|}
\hline 15 & Pyrenula nitida & 1.19 & 1.72 & 1.19 & 3.28 & 5.26 & 3.279 & 4.1 & 11.82 \\
\hline 16 & Pyrenula sp. & 4.76 & 5.17 & 4.76 & - & - & - & 14.69 & 0 \\
\hline 17 & $\begin{array}{l}\text { Pyrhospora } \\
\text { quernea }\end{array}$ & 26.56 & $\begin{array}{l}15.5 \\
2\end{array}$ & $\begin{array}{l}26.5 \\
6\end{array}$ & 22.54 & $\begin{array}{l}15.7 \\
9\end{array}$ & $\begin{array}{l}22.54 \\
1\end{array}$ & 68.63 & 60.87 \\
\hline 18 & Rimelia reticulate & 5.10 & 6.03 & 5.10 & - & - & - & 16.23 & - \\
\hline 19 & Usnea dasypoga & 5.44 & 6.03 & 5.44 & - & - & - & 16.91 & - \\
\hline 20 & $\begin{array}{l}\text { Usnea } \\
\text { fillipendula }\end{array}$ & 0.68 & 5.17 & 0.68 & - & - & - & 6.53 & - \\
\hline 21 & $\begin{array}{l}\text { Verrucaria } \\
\text { Maura }\end{array}$ & 10.14 & 8.62 & $\begin{array}{l}10.1 \\
4\end{array}$ & 4.20 & 7.37 & 4.201 & 28.89 & 15.77 \\
\hline 22 & Verrucaria sp. & 0.28 & 0.86 & 0.28 & - & - & - & 1.43 & - \\
\hline Total & & 100 & 100 & 100 & 100 & 100 & 100 & 300 & 300 \\
\hline
\end{tabular}

\subsection{Physical properties of environmental chemistry}

Observation of ecological characteristics carried out by measuring physical chemical factors, namely; air temperature, air humidity, and light intensity. This measurement was carried out only once for each plot as primary data and secondary data was obtained from the Sampali Meteorology and Geophysics Agency in Medan.

Table 3. Characteristics of ecology in two research sites

\begin{tabular}{|c|c|c|c|c|c|c|}
\hline \multirow{3}{*}{ Tree } & \multicolumn{6}{|c|}{ Environmental Conditions } \\
\hline & \multicolumn{2}{|c|}{ Temperature $\left({ }^{0} \mathrm{C}\right)$} & \multicolumn{2}{|l|}{ Humidity } & \multicolumn{2}{|c|}{ Light Intensity } \\
\hline & Aek Nauli & Tahura & Aek Nauli & Tahura & Aek Nauli & Tahura \\
\hline I & 23 & 20 & 57 & 81 & 945 & 915 \\
\hline II & 24 & 22 & 70 & 78 & 745 & 812 \\
\hline III & 19 & 23 & 82 & 77 & 140 & 822 \\
\hline IV & 24 & 21 & 43 & 79 & 1869 & 802 \\
\hline $\mathrm{V}$ & 22 & 23 & 67 & 77 & 604 & 987 \\
\hline VI & 23 & 20 & 53 & 80 & 1621 & 921 \\
\hline VII & 23 & 21 & 56 & 85 & 982 & 875 \\
\hline VIII & 23 & 21 & 58 & 74 & 570 & 993 \\
\hline IX & 24 & 21 & 62 & 75 & 468 & 904 \\
\hline $\mathrm{X}$ & 24 & 20 & 52 & 73 & 327 & 913 \\
\hline Rata-rata & 22.9 & 21.2 & 60 & 77.9 & 827.1 & 894.4 \\
\hline
\end{tabular}

Based on table 3 , the results of measurements of air humidity on average at the two study locations were $58.29 \%$ and $77.41 \%$. this supports the opinion Pratiwi (2006) which states that 
lichens like dry places with humidity of $40 \%$ to $69 \%$ (Pratiwi, 2006). the average air humidity in aek nauli is in the range of $40 \%-69 \%$, so there are more types of lichens in that location. where as the average humidity in tahura is above that range, so there are fewer types of lichens in tahura. nevertheless the growth and development of lichens in an area is not only determined by the humidity factor of the air. growth and development of lichens in frankincense trees in the two study sites were also influenced by the content of pollutants in the air, because the area contained a trans-sumatra road.

The measurement of air temperature at the aek nauli location ranges from $19^{\circ} \mathrm{c}-24^{\circ} \mathrm{c}$ and in the tahura region, ranging from $20^{\circ} \mathrm{c}-23^{\circ} \mathrm{c}$. according to Pratiwi (2006) high temperatures will increase respiration rate and reduce the rate of photosynthesis. temperature conditions with a range of values at the two study sites support the growth and development of the lichens because they are in normal plant threshold conditions.

\subsection{Index of Diversity / Abundance of Lichens}

The distribution or distribution pattern of each type of lich is determined using the ratio ratio formula with the middle value. the following is a graph of the distribution pattern of a type of lichens found in the two study locations. according to krebs if the distribution index is $1(\mathrm{v} / \mathrm{m}=1)$ then the distribution of the species is random, if the distribution index is $>1$ then the distribution is clustered, and if the distribution index is $<1$ then the distribution is uniform (Pratiwi, 2006). the distribution pattern or level of distribution obtained from the two locations is almost more than $1(>1)$ and there is one type in the aek nauli forest area where the distribution is equal to $1(=1)$, namely verrucaria sp. from these results it is known that the distribution pattern of lichens is more than $1(>1)$ the distribution is grouped and the distribution pattern of lichens is equal to $1(=1)$ the distribution is random. this shows that the type of distribution pattern in the two study locations almost entirely reflects heterogeneous reproductive modes, group behavior, and one type reflects homogeneity and non-selective patterns of behavior. this statement is justified by Kusmana (1995), that there are 3 types of distribution patterns, namely: (1) random or random, this pattern reflects homogeneity and patterns of non-selective behavior, (2) clumped, this pattern reflects heterogeneous habitats, reproductive modes, group behavior, etc., (3) uniform or uniform, reflecting the existence of negative interactions between individuals such as competition for space, nutrients or light.

\section{Conclusion}

The results showed a high diversity and obtained 22 species of lichens, the 19 species in aek nauli and 14 species in tahura consisting of 11 genera. thallus lichens forms encountered on two locations is crustose, foliose and fruticose, but the squamulose type is not found. data analysis relative density of vegetation $(\mathrm{kr})$ relative frequency $(\mathrm{fr})$ relative dominance $(\mathrm{dr})$ and importance value (np), the highest for aek nauli consecutive pyrhospora quernea the type and the highest consecutive tahura the type of pertusaria amara. physical-chemical condition of the habitat that supports the growth and development of this type of tourist forest lichens tahura, karo is the average temperature $(21.20 \mathrm{c})$, humidity $(77.9 \%)$ and light intensity $(894,4$ joule), but at aek nauli is the average temperature $(22,90 \mathrm{c})$, humidity $(60 \%)$ and light intensity (827,1 joule). almost all types of lichens both locations showed clumped distribution pattern. 
the highest dispoersion of lichens is lecanora conizoides and the lower distribution of lichens is usnea filifumdea.

\section{SUGGESTIONS}

Need further identification at lepraria sp.; peltigere sp.; pyrenula sp.; verrucaria sp. physical chemistry environmental factors need to be added to look at other factors that influence real against the presence of lichens. other factors include the density of the heading, direction and wind speed are thought to affect the pattern of spread of lichens.

Acknowledgments. The authors wish to thanks Prof. Dr. Syawal Gultom, M.Pd rektor State University of Medan for HIBAH KDBK and supporting the research data.

\section{References}

[1]Barbour, G.M., J.K. Burk., W.D. Pitts., (1987), Terrestrial Plant Ecology, The Benyamin/Cummings Publishing Company. Inc, Los Angeles.

[2]Darma, T. I. G. K., Soetrisno, H., Dadan, J. 1998. Jenis-jenis lumut kerak yang berkembang pada tegakan pinus dan karet. Jurnal Managemen Hutan Tropika IV (1-2) : 710

[3]Duades, R. 2004. Studi Keanekaragaman Tumbuhan Obat Di Hutan Penelitian Aek Nauli Kabupaten Simalungun. Skripsi FMIPA, Medan. Unimed

[4]Hasairin, A., Pasaribu, N., Sudirman, L. I., \& Widhiastuti, R. (2014). Accumulation of Lead $(\mathrm{Pb})$ in the Thallus Lichenes Contained in Mahogany Tree Stands of Roadside of Medan City. Environment and Pollution, 4(1). doi:10.5539/ep.v4n1p19

[5]Krebs., (1978), Ecology, The Experimental Analysis of Distribution and Abundance, Third Edition Harper and Row Distribution, New York.

[6]Kusmana, C. \& Istomo., (1995), Ekologi Hutan, Bahan Kuliah Laboratorium Ekologi Hutan, Fakultas Kehutanan, Bogor, IPB.

[7]Michael, P., (1995), Metode Ekologi Untuk Penyelidikan Lapangan dan Laboratorium, UI Press, Jakarta.

[8]Murningsih, M., \& Mafazaa, H. (2016). Jenis-Jenis Lichen Di Kampus Undip Semarang. Bioma : Berkala Ilmiah Biologi, 18(2), 20-29 doi:10.14710/bioma.18.2.20-29

[9]Murningsih., Husna, Mafaza., (2016), Jenis-Jenis Lichen Di Kampus Undip Semarang, Jurnal Bioma 18 (1) : 20-29.

[10]McCune, B. 2010. Key to the Lichen Genera of the Pacific Northwest. Dept. Botany \& Plant Pathology, Oregon State University : 1-97

[11]Odum, E. P. 1993. Dasar-Dasar Ekologi. UGM Press. Yogyakarta.

[12]Phillips, R. 1990. Grasses, Ferns, Mosses \& Lichens. Oxford University Press

[13]Pratiwi, M. E. 2006. Kajian Lumut Kerak Sebagai Bioindikator Kualitas Udara. Institut Pertanian Bogor. Bogor

[14]Sipman, H. J. M. 2003. Key to the lichen genera of Bogor, Cibodas and Singapore. http://www.bgbm.org/sipman/keys/Javagenera.htm.

[15]Tjitrosoepomo, G. 1989. Taksonomi Tumbuhan. Gadjah Mada University Press. Yogyakarta. 
